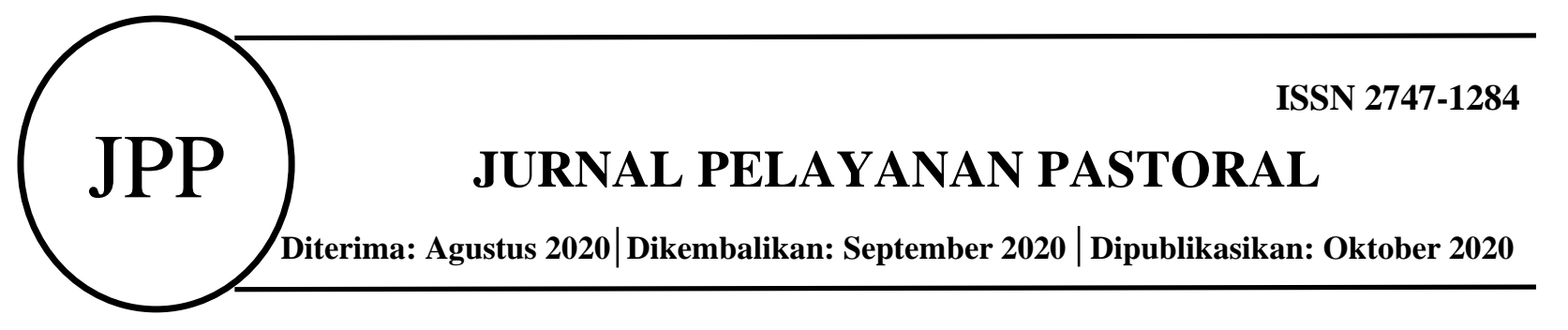

\title{
PEMBERDAYAAN PENYANDANG DISABILITAS MELALUI BALAI LATIHAN KERJA BHAKTI LUHUR
}

\author{
Lorentius Goa*1 \\ ${ }^{1}$ Sekolah Tinggi Pastoral -IPI Malang \\ Jurusan Kateketik Pastoral, Prodi Pendidikan dan Pengajaran Agama Katolik \\ e-mail: ${ }^{1}$ lorensgoa@gmail.com
}

\begin{abstract}
Abstrak
Penyandang disabilitas merupakan topik yang hangat dibahas di berbagai negara maju termasuk di negara kita Indonesia. Hal ini karena penyandang disabilitas merupakan kelompok minoritas yang sering kali tidak diperhatikan dalam pemenuhan hak-haknya. Salah satu cara agar para penyandang disabilitas dapat memperoleh hidup yang layak adalah dengan melalui pemberdayaan. Yayasan Bhakti Luhur sendiri memiliki visi untuk memberdayakan penyandang bilitas melalui berbagai kegiatan yang salah satunya melalui balai latihan kerja, yang didampingi oleh tenagatenaga profesional. Penyandang disabilitas yang diberdayakan di balai latihan kerja ini adalah penyandang disabilitas yang mampu latih. Pemberdayaan yang dilakukan adalah Pembuatan Furnitur dan Mebel rumah tangga, Alat-alat rumah tangga, Produksi Paving Stone manual, Kerajinan kayu untuk playgroup, Lukisan dan Lukisan Rajutan (streaming), Percetakan dan Offset, Pembuatan Pot Tanaman, Tanaman Hias, dan Berternak ikan nila dan lele.
\end{abstract}

Kata kunci: Pemberdayaan Penyandang Disabilitas, Balai Latihan Kerja.

\begin{abstract}
People with disabilities are a hot topic to be discussed in various developed countries including our country, Indonesia. The reason is, people with disabilities are a group of minorities who are often neglected in fulfilling their rights. One of the ways for people with disabilities can have a decent life is through empowerment. The Bhakti Luhur Foundation itself has the vision to empower people with disabilities through various activities, one of which is through a job training center accompanied by professional staff. People with disabilities who are empowered in this job training center are people with disabilities who can train. The empowerment carried out is the manufacture of household furniture, household utensils, manual paving stone production, woodcraft for playgroups, painting and knitting painting (streaming), printing and offsetting, making plant pots, ornamental plants, and raising tilapia and catfish.
\end{abstract}

Keywords: Empowerment of People with Disabilities, Job Training Center 


\section{PENDAHULUAN}

Setiap orang di dunia ini dilahirkan dengan berbagai perbedaan. Tidak ada seorangpun yang terlahir sama meskipun mereka adalah kembar. Perbedaan tersebut bisa melalui perbedaan fisik maupun non-fisik. Merupakan hal yang wajar jika kita berbeda dalam segala hal, contohnya; perbedaan warna kulit, bentuk fisik, kecerdasan, dan perbedaan-perbedaan lainnya. Oleh karena itu, bukan hal yang mengherankan jika dalam kehidupan sehari-hari kita sering menjumpai banyak saudara-saudara kita yang merupakan penyandang disabilitas.

Permasalahan kemiskinan dan persoalan-persoalan yang cukup kompleks membutuhkan perhatian semua pihak secara bersama dan terkoordinasi. Terutama diskriminasi, marginalisasi, stigma dan kekerasan terhadap penyandang disabilitas merupakan persoalan serius. Salah satu solusi yang dianggap cukup baik adalah melalui pemberdayaan penyandang disabilitas. Pemberdayaan merupakan jalan keluar untuk menciptakan iklim dan tatanan masyarakat yang sejahtera dalam segala aspek kehidupan. Ini berarti, bahwa semua individu dalam suatu wilayah geografis mempunyai hak dan kewajiban untuk turut membangun wilayahnya tanpa ada pembatasan terhadap peran dan fungsi.

Undang-undang Republik Indonesia No. 8 Tahun 2016 tentang penyandang disabilitas, bagian ketujuh pasal 11 membahas mengenai hak pekerjaan, kewirausahaan, dan koperasi untuk Penyandang Disabilitas meliputi hak: a) Memperoleh pekerjaan yang diselenggarakan oleh pemerintah, pemerintah daerah, atau swasta tanpa diskriminasi; b) Memperoleh upah yang sama dengan tenaga kerja yang bukan Penyandang Disabilitas dalam jenis pekerjaan dan tanggung jawab yang sama; c) Memperoleh akomodasi yang layak dalam pekerjaan; d) tidak diberhentikan karena alasan disabilitas; e) Mendapatkan program kembali kerja; f) Penempatan kerja yang adil, proporsional, dan bermartabat; g) Memperoleh kesempatan dalam mengembangkan jenjang karier serta segala hak normatif yang melekat didalamnya.; h) memajukan usaha, memiliki pekerjaan sendiri, wiraswasta, pengembangan koperasi, dan memulai usaha sendiri serta Peraturan Daerah Provinsi Jawa Timur Nomor 3 Tahun 2013 bagian ketiga pasal 15-34 tentang ketenagakerjaan dan usaha.

Pemerintah sampai saat ini masih menghadapi masalah yang besar dalam menangani tenaga kerja penyandang disabilitas, karena penanganan tenaga kerja penyandang disabilitas jauh lebih kompleks dibanding dengan penanganan masalah pengangguran tenaga kerja orang normal, baik yang menyangkut (a) kesempatan, (b) penguasaan keterampilan, (c) persyaratan yang dipersyaratkan oleh dunia kerja, maupun (d) kondisi internal penyandang disabilitas sendiri. Oleh karena itu program layanan rehabilitasi karya bagi penyandang disabilitas masih harus ditingkatkan.

Banyak faktor yang menjadi kendala, diantaranya: (1) penyandang disabilitas memiliki keterbatasan kemampuan, sehingga memerlukan bimbingan yang kontinyu; (2) pemberian pendidikan keterampilan kepada penyandang disabilitas tidak dapat hanya sepotong-sepotong, melainkan harus secara utuh; (3) selama ini pelaksanaan pendidikan keterampilan di SLB masih sepotong-sepotong oleh karena harus memenuhi target kurikulum dan hanya sesuai dengan jadwal pelajaran yang tersedia; (4) selama ini belum ada model layanan rehabilitasi karya bagi siswa SLB yang sistematik dan integrated; (5) kurikulum keterampilan di SLB belum berwawasan lingkungan sehingga kendala dalam pengadaan bahan baku, pelaksanaan pendidikan serta kualitas produkbelum memenuhi yang diharapkan; dan (6) pendidikan keterampilan yang ada di SLB belum banyak mempertimbangkan kemampuan penyandang disabilitas secara individual, sehingga sangat sulit diterapkan di sekolah-sekolah. 
Berkat perjuangan dan kerja keras, tak sedikit penyandang disabilitas yang sukses dalam meraih cita-cita. Perlakuan manusiawi dan humanistis adalah merupakan kunci pokok terwujudnya masyarakat bangsa yang peduli pada masa depan setiap penyandang disabilitas. Kalau tidak dimulai sekarang, kapan lagi kita peduli?

Menurut Wilson (1996) terdapat 7 tahapan dalam siklus pemberdayaan masyarakat atau anak disabilitas. Tahap pertama yaitu keinginan dari masyarakat atau kaum disabilitas sendiri untuk berubah menjadi lebih baik artinya memperoleh pekerjaan yang lebih baik. Pada tahap kedua, masyarakat atau kaum disabilitas diharapkan mampu melepaskan halangan-halangan atau faktor-faktor yang bersifat resistensi terhadap kemajuan dalam dirinya dan komunitasnya. Pada tahap ketiga, masyarakat/kaum disabilitas diharapkan sudah menerima kebebasan tambahan dan merasa memiliki tanggung jawab dalam mengembangkan dirinya dan komunitasnya. Tahap keempat yaitu upaya untuk mengembangkan peran dan batas tanggung jawab yang lebih luas, hal ini juga terkait dengan minat dan motivasi untuk melakukan pekerjaan dengan lebih baik. Pada tahap kelima ini hasil-hasil nyata dari pemberdayaan mulai kelihatan, dimana peningkatan rasa memiliki yang lebih besar menghasilkan keluaran kinerja yang lebih baik. Pada tahap keenam telah terjadi perubahan perilaku dan kesan terhadap dirinya, dimana keberhasilan dalam peningkatan kinerja mampu meningkatkan perasaan psikologis di atas posisi sebelumnya. Pada tahap ketujuh masyarakat/kaum disabilitas yang telah berhasil dalam memberdayakan dirinya, paling tidak dalam memenuhi kebutuhan hidupnya sehari-hari.

\section{METODE PENELITIAN}

Pada penelitian ini peneliti menggunakan metode penelitian kualitatif. Penelitian kualitatif adalah penelitian yang menggunakan latar alamiah, dengan maksud menafsirkan fenomena yang terjadi dan dilakukan dengan jalan berbagai metode yang ada (Moleong 2010, 5). Adapun tujuan dari penelitian kualitatif agar dapat mendeskripsikan secara lebih rinci, lebih jelas dan lebih akurat (Bungin 2001:147). Jadi yang dihasilkan oleh penelitian ini adalah data deskriptif yang berisi tentang gejala-gejala sosial, fakta-fakta sosial, lalu makna dari fakta-fakta yang ditemukan saat penelitian. Dengan menggunakan pendekatan kualitatif, penelitian ini diharapkan mampu mendeskripsikan tentang keadaan yang sebenarnya (naturalistik) dilapangan.

Implikasi dari penelitian ini adalah bertumpu pada pencarian data sebanyak-banyaknya. Data dilapangan dikumpulkan sejauh dianggap cukup, guna memberikan gambaran maksimal yang diinginkan untuk menentukan, membuktikan dan mengembangkan secara sistematis. Oleh karena itu, dalam penelitian ini penulis berusaha untuk menggambarkan secara jelas mengenai upaya yang telah dilakukan para pendamping pelatihan Kerja Bhakti Luhur dalam pemberdayaan anak disabilitas dan jenis-jenis pendidikan vokasional yang diberikan pada mereka serta proses pelaksanaannya.

\section{HASIL DAN PEMBAHASAN}

\section{Pengertian Pemberdayaan}

Pemberdayaan menurut arti secara bahasa adalah proses, cara, perbuatan membuat berdaya, yaitu kemampuan untuk melakukan sesuatu atau kemampuan bertindak yang berupa akal, ikhtiar atau upaya (Depdiknas, 2003). Masyarakat adalah kesatuan hidup manusia yang berinteraksi menurut suatu sistem adat istiadat tertentu yang bersifat kontinyu, dan yang terikat oleh suatu rasa identitas bersama (Koentjaraningrat 2009, 116). Dalam beberapa kajian mengenai pembangunan komunitas, pemberdayaan masyarakat sering dimaknai sebagai upaya untuk memberikan kekuasaan agar suara mereka didengar guna memberikan kontribusi kepada 
perencanaan dan keputusan yang mempengaruhi komunitasnya. Pemberdayaan adalah proses transisi dari keadaan ketidakberdayaan ke keadaan kontrol relatif atas kehidupan seseorang, takdir, dan lingkungan (Sadan 1997, 13).

Istilah pemberdayaan ini seringkali berkaitan dengan hal-hal yang berhubungan dengan ekonomi, yaitu meningkatkan kemampuan ekonomi individu yang merupakan prasyarat pemberdayaan. Craig dan Mayo (1995) menyatakan bahwa perspektif Marxis terhadap pemberdayaan dalam masyarakat kapitalis tidak dapat dipisahkan dari kekuatan ekonomi. Pemberdayaan ini bersinggungan erat dengan kepentingan-kepentingan kapitalis lewat kerjasama transnasional yang berskala global. Dalam keadaan semacam itu, pemberdayaan masyarakat miskin dibatasi oleh gerakan-gerakan kapitalis. Karena itu, masyarakat miskin dan sangat miskin harus diberdayakan untuk dapat berpartisipasi lebih efektif dalam proyek dan program pembangunan yang dicanangkan pemerintah. Kemampuan tawar-menawar (bargaining position) dan pelayanan terhadap masyarakat miskin pun semakin meningkat. Namun demikian, keadaan ini tidak terlepas dari masalah untung rugi dalam pasar global.

Namun sesungguhnya terminologi pemberdayaan tidak sebatas ekonomi, tapi juga mengandung makna tindakan usaha perbaikan di segala aspek termasuk hal yang berkaitan dengan sosial, budaya, politik, psikologi, baik secara individu maupun kolektif yang berbeda menurut kelompok etnik dan kelompok sosialnya (Pranaka et.al, 1996).

Pendekatan pemberdayaan pada intinya merupakan upaya menghapuskan subordinasi penyandang disabilitas, dan melepaskannya dari tindakan diskriminatif. Namun konsep pemberdayaan yang diterapkan pada penyandang disabilitas disesuaikan dengan kebutuhannya. Ada dua pendekatan yang digunakan untuk melakukan pemberdayaan pada penyandang disabilitas (Coleridge1997, 36) yakni: (1) Model Medis. Model Medis menganggap kecacatan sebagai suatu abnormalitas, sehingga orang yang mengalami kecacatan harus dinormalkan, dikoreksi, ditanggulangi dan disembuhkan, sehingga hambatan yang mereka hadapi di masyarakat dapat diatasi, dan pemberdayaan penyandang disabilitas tersebut bisa berjalan. (2) Model Sosial. Model Sosial disusun berdasarkan pemahaman bahwa penyatuan diri penyandang disabilitas diartikan sebagai proses merobohkan rintangan-rintangan dan menjinakkan ranjau-ranjau sosial. Model ini menekankan aspek perubahan sikap masyarakat terhadap penyandang disabilitas yang menghambat kemandirian dan pengembangan dirinya.

\section{Teori Pemberdayaan Disabilitas}

Teori pemberdayaan masyarakat/disabilitas memberikan petunjuk apa yang sebaiknya dilakukan di dalam situasi tertentu. Teori dapat dalam bentuk luas atau ringkas mengenai polapola interaksi dalam masyarakat atau menggambarkan pola yang terjadi dalam situasi tertentu (contoh: masyarakat, organisasi, atau kelompok populasi tertentu).

Sebuah teori dalam pemberdayaan masyarakat/disabilitas dapat ditemukan atau diungkap menggunakan dua pendekatan. Pendekatan pertama adalah Deductive Theory Construction yaitu teori yang sudah ada atau ditemukan diawal kemudian dilakukan penelitian pemberdayaan pada masyarakat/disabilitas. Pendekatan kedua adalah Konstructive theory yaitu teori yang belum ada atau masih di duga dan untuk menyusunnya dilakukan penelitian pemberdayaan pada masyarakat/disabilitas.

\section{Teori Ketergantungan Kekuasaan (Power-Dependency)}

Pada konteks pemberdayaan maka teori ketergantungan dikaitkan dengan kekuasaan yang biasanya dalam bentuk kepemilikan uang atau modal. Untuk mencapai suatu kondisi berdaya, 
kuat, mandiri, maka sekelompok masyarakat atau anak disabilitas harus mempunyai keuangan atau modal yang kuat. Selain uang atau modal, maka ilmu pengetahuan/knowledge dan aspek people/sekumpulan orang/massa yang besar juga harus dimiliki agar kaum disabilitas tersebut mempunyai power. Kaum disabilitas yang memiliki power maka mereka itu akan berdaya dalam masyarakat.

\section{Teori Sistem (The Soscial System)}

Talcott Parsons melahirkan teori fungsional tentang perubahan. Seperti para pendahulunya, Parsons juga menganalogikan perubahan sosial pada kaum disabilitas seperti halnya pertumbuhan pada mahkluk hidup. Komponen utama pemikiran Parsons adalah adanya proses diferensiasi. Parsons berasumsi bahwa setiap masyarakat atau kaum disabilitas tersusun dari sekumpulan subsistem yang berbeda berdasarkan strukturnya maupun berdasarkan makna fungsionalnya bagi masyarakat atau kaum disabilitas yang lebih luas. Ketika masyarakat atau kaum disabilitas itu berubah, umumnya mereka akan tumbuh dengan kemampuan yang lebih baik untuk menanggulangi permasalahan hidupnya. Dapat dikatakan Parsons termasuk dalam golongan yang memandang optimis sebuah proses perubahan (Ritzer 2012, 25).

Parsons menyampaikan empat fungsi yang harus dimiliki oleh sebuah sistem agar mampu bertahan, yaitu : Adaptasi, sebuah sistem harus mampu menanggulangi situasi eksternal yang gawat. Sistem harus dapat menyesuaikan diri dengan lingkungan. Pencapaian, sebuah sistem harus mendefinisikan dan mencapai tujuan utamanya. Integrasi, sebuah sistem harus mengatur hubungan antar bagian yang menjadi komponennya. Sistem juga harus dapat mengelola hubungan antara ketiga fungsi penting lainnya. Pemeliharaan pola, sebuah sistem harus melengkapi, memelihara dan memperbaiki motivasi individual maupun pola-pola kultural yang menciptakan dan menopang motivasi (Ritzer 2004, v).

\section{Anak Disabilitas (Anak berkebutuhan Khusus)}

Anak berkebutuhan khusus (ABK) adalah anak dengan karakteristik khusus yang berbeda dengan anak pada umumnya tanpa selalu menunjukan pada ketidakmampuan mental, emosi atau fisik. Yang termasuk kedalam ABK antara lain: tunanetra, tunarungu, tunagrahita, tunadaksa, tunalaras, kesulitan belajar, gangguan prilaku, anak berbakat, anak dengan gangguan kesehatan. Istilah lain bagi anak berkebutuhan khusus adalah anak luar biasa dan anak cacat. Karena karakteristik dan hambatan yang dimiliki, ABK memerlukan bentuk pelayanan khusus yang disesuaikan dengan kemampuan dan potensi mereka, contohnya bagi tunanetra mereka memerlukan modifikasi teks bacaan menjadi tulisan Braille dan tunarungu berkomunikasi menggunakan bahasa isyarat dan lain sebagainya.

Anak berkebutuhan khusus di definisikan sebagai anak yang memerlukan layanan khusus untuk mengembangkan potensi kemanusiaan mereka secara sempurna (Hallahan dan Kauffman, 1986). Anak luar biasa, juga dapat di definisikan sebagai anak yang berkebutuhan khusus. Anak luar biasa di sebut sebagai anak berkebutuhan khusus, karena dalam rangka untuk memenuhi kebutuhan hidupnya, anak ini membutuhkan bantuan layanan pendidikan, layanan sosial, layanan bimbingan dan konseling, dan berbagai jenis layanan lainnya yang bersifat khusus.

Jenis-jenis layanan tersebut di berikan secara khusus kepada anak yang berkebutuhan khusus oleh pihak yang berkompeten pada setiap jenis layanan itu. Adapun yang termasuk pihakpihak yang berkompeten dalam memberikan layanan sosial, yang berijazah pendidikan luar biasa, pekerja sosial, konselor/petugas bimbingan konseling, dan ahli lain yang relevan dengan jenis layanan yang di berikan kepada anak berkebutuhan khusus. 


\section{Yayasan Bhakti Luhur}

Yayasan Bhakti Luhur memiliki visi memberdayakan anak penyandang disabilitas yang karena salah satu atau beberapa sebab seperti fisik, psikis, mental, sosio-ekonomi yang menyebabkan keterbelakangan dalam perkembangannya untuk mencapai kemandirian di tengah keluarga dan masyarakatnya. Sedangkan Misi untuk mencapai visi tersebut adalah, menjangkau yang tak terjangkau melalui rehabilitasi yang dilakukan di dalam institusi dan di tengah masyarakat.

Yayasan Bhakti Luhur sebagai sebuah lembaga sosial bagi anak berkebutuhan khusus yang tidak membedakan siapa anak-anak yang diasuh atau yang dilayani. Sehingga sistem pelayanan kepada anak berkebutuhan khusus juga menerima semua jenis anak berkebutuhan khusus. Anak berkebutuhan khusus yang dilayani di wisma Putera Bhakti Luhur digolongkan menjadi tiga (3) yakni: 1) Anak mampu rawat atau yang digolongkan disabilitas berat. Anak yang digolongkan mampu rawat yakni anak-anak yang tidak bisa melakukan aktivitasnya sendiri dan harus dibantu penuh oleh pengasuh atau pendamping. 2) Anak mampu latih atau yang digolongkan disabilitas sedang. Anak yang digolongkan mampu latih adalah anak-anak yang masih bisa dilatih melalui latihan-latihan praktis dan juga keterampilan-keterampilan lainnya. 3) Anak mampu didik atau yang digolongkan disabilitas ringan.

\section{Strategis Pemberdayaan Latihan Kerja}

Menurut UU No.19 Tahun 2011 tentang Pengesahan Convention on the Rights of Persons with Disabilities (Konvensi mengenai Hak-Hak Penyandang Disabilitas) bahwa Penyandang disabilitas termasuk mereka yang memiliki keterbatasan fisik, mental, intelektual, atau sensorik dalam jangka waktu lama di mana ketika berhadapan dengan berbagai hambatan, hal ini dapat menghalangi partisipasi penuh dan efektif mereka dalam masyarakat berdasarkan kesetaraan dengan yang lainnya. Mereka seringkali kurang dihargai dan bahkan dicap sebagai orang yang malas, lemah yang disebabkan oleh dirinya sendiri. Padahal ketidakberdayaan mereka seringkali merupakan akibat dari adanya kekurangadilan dan diskriminasi dalam aspek-aspek kehidupan tertentu.

Ketidakberdayaan penyandang disabilitas ini disebabkan oleh beberapa faktor seperti: ketiadaan jaminan ekonomi, ketiadaan pengalaman dalam arena politik, ketiadaan akses terhadap informasi, ketiadaan dukungan finansial, ketiadaan pelatihan-pelatihan dan adanya ketegangan fisik maupun emosional (Suharto 2010, 60).

Para teoritis seperti Seeman, Seligman, dan Learner meyakini bahwa ketidakberdayaan yang dialami oleh sekelompok masyarakat seperti penyandang disabilitas merupakan akibat dari proses internalisasi yang dihasilkan dari interaksi mereka (penyandang disabilitas) dengan masyarakat. Penyandang disabilitas menganggap diri mereka lemah dan tidak berdaya karena masyarakat memang menganggapnya demikian. Seeman menyebut keadaan ini dengan istilah "alienasi". Sementara Seligman menyebutnya sebagai ketidakberdayaan yang dipelajari (learned helplessness) dan Learned menamakannya dengan istilah ketakberdayaan surplus atau surplus powerlessness (Suharto 2006, 30).

Ketidakberdayaan dapat berasal dari penilaian diri yang negatif, interaksi negatif dengan lingkungan atau berasal dari blokade dan hambatan yang berasal dari lingkungan yang lebih besar. (1) Penilaian diri yang negatif. Ketidakberdayaan dapat berasal dari adanya sikap penilaian yang negatif yang ada pada diri seseorang yang terbentuk akibat adanya penialian negatif dari orang lain. (2) Interaksi negatif dengan orang lain. Ketidakberdayaan dapat bersumber dari pengalaman negatif dalam interaksi antara korban yang tertindas dengan sistem di luar mereka yang 
menindasnya. (3) Lingkungan yang lebih luas. Lingkungan yang lebih luas dapat menghambat peran dan tindakan kelompok tertentu. Situasi ini dapat mengakibatkan tidak berdayanya kelompok yang tertindas tersebut dalam mengekspresikan atau menjangkau kesempatankesempatan yang ada di masyarakat misalnya kesempatan dalam memperoleh pekerjaan dan Pendidikan (Suharto 2006, 35.

Dengan demikian, dibutuhkan adanya suatu usaha untuk melepas atau mengeluarkan penyandang disabilitas dari ketidakberdayaan yaitu melalui upaya pemberdayaan. Pemberdayaan adalah membantu klien memperoleh daya untuk mengambil keputusan dan menentukan tindakan yang akan ia lakukan yang terkait dengan diri mereka, termasuk mengurangi efek hambatan pribadi dan sosial dalam melakukan tindakan (Adi 2003, 40). Hal ini dilakukan melalui peningkatan kemampuan dengan rasa percaya diri untuk membentuk masa depan sesuai dengan keinginan mereka.

Proses pemberdayaan kepada anak-anak disabilitas yang tergolong dalam kategori kemampuan sedang, mereka inilah yang dilatih dengan berbagai keterampilan di workshop atau Balai Latihan Kerja Bhakti Luhur. Balai latihan kerja ini berada di Jalan Setaman Kota Malang, yang terdiri dari berbagai program latihan kerja bagi anak disabilitas. Balai Latihan Kerja Bhakti Luhur ini didampingi oleh delapan orang tenaga profesional setiap harinya. Pada pendamping ini dibagi dalam kelompok bidang keterampilan sesuai dengan bakat/minatnya masing-masing, sehingga anak disabilitas juga dibagi sesuai dengan kemampuan mereka dalam bidang-bidang tertentu.

Jadi program latihan kerja merupakan proses kegiatan yang diarahkan kepada anak disabilitas dalam usaha mencapai keterapilan yang diharapkan dan juga demi memotivasi mereka agar bisa mandiri dalam latihan kerja tersebut. Program yang dilaksanakan di Balai Latihan Kerja Bhakti Luhur bagi anak disabilitan antara lain: Pembuatan Furnitur dan Mebel rumah tangga, alatalat rumah tangga, produksi paving stone manual, kerajinan kayu untuk playgroup, lukisan dan lukisan rajutan (streaming), percetakan dan Offset, pembuatan pot tanaman, tanaman Hias, dan berternak ikan nila dan lele.

\section{Hasil Pemberdayaan}

Untuk menumbuhkan rasa percaya diri dan diterima dalam masyarakat, seorang disabilitas termotivasi baik dari dalam dirinya maupun dari lingkungan masyarakat sekitarnya. Dengan demikian diharapkan agar sebagai sesama saling menolong sesama terutama bagi mereka yang berkebutuhan khusus.

Menurut Munawwir Yusuf yang dikutip oleh Joppy Liando dan Aldjon Dapa dalam bukunya yang berjudul "Pendidikan Anak Berkebutuhan Khusus Dalam Perspektif Sistem Sosial", mengatakan bahwa indikator keberhasilan program pemberdayaan anak disabilitas ditinjau dari dua sisi yaitu: bagi anak disabilitas sendiri dan juga bagi masyarakat sekitar. Bagi disabilitas sendiri dikatakan berhasil bila: (1) Telah pulihnya rasa harga diri dan percaya diri penyandang disabilitas sendiri. (2) Memiliki kemauan dan kemampuan untuk mengembangkan diri melalu latihan kerja. (3) Dapat secara mandiri melakukan kegiatannya sehari-hari dan tidak tergantung pada orang lain. (4) Memiliki kesadaran yang tinggi untuk berperan serta dalam seluruh bidang kehidupan masyarakat.

Dari sisi masyarakat indikatornya adalah: (1) Adanya perubahan perilaku yang positif dari masyarakat terhadap usaha kesejahteraan sosial bagi penyandang disabilitas. (2) Meningkatkan dan terciptanya kesadaran, kemauan, dan kemampuan masyarakat dalam mendukung program- 
program usaha kesejahteraan sosial, sehingga penanganan latihan kerja oleh kaum disabilitas dapat dirasakan oleh masyarakat sekitar (Joppy 2007, 178-179).

\section{KESIMPULAN}

Belajar dari pengamalan bahwa perlakuan diskriminatif, baik secara struktural (kebijakan negara) maupun kultural (penerimaan masyarakat) terhadap penyandang disabilitas hanya menciptakan masalah baru, yakni ketidakberdayaan mereka dalam kehidupan individu dan bermasyarakat. Penyandang disabilitas semakin sulit mengembangkan sumber daya manusianya, dan selalu tergantung pada uluran tangan pihak lain. Perjuangan penyandang cacat untuk bebas dari diskriminasi dan ketidakadilan tidak saja menyangkut aksesibilitas dalam sistem sosial, politik, ekonomi, budaya, serta lingkungan infrastruktur yang ada, namun justru yang lebih berat adalah peluang mengubah asumsi dan ideologi cacat-normal yang telah mengakar di masyarakat. Dalam konteks itulah perubahan ideologi negara dan masyarakat menuju "sensitif terhadap penyandang disabilitas" menduduki posisi penting.

Melalui pemberdayaan penyandang disabilitas dileburkan dalam masyarakat secara inklusif, yang tentunya membutuhkan penerimaan dari masyarakat pula secara bertahap, sehingga seiring dengan proses yang terus berjalan, penyandang disabilitas pada akhirnya diterima sebagaimana orang normal lainnya. Pada titik inilah penyandang disabilitas merasa nyaman dalam kehidupannya sehingga mampu berkreasi dan meningkatkan SDM-nya secara berkesinambungan. Tentu didukung pula oleh kebijakan negara yang tidak lagi diskriminatif.

Bhakti Luhur adalah salah satu lembaga swasta yang juga memberdayakan para penyandang disabilitas melalui latihan kerja di Balai Latihan Kerja Bhakti Luhur, yang setiap harinya mendampingi anak-anak penyandang disabilitas oleh tenaga-tenaga yang profesional dibidangnya masing-masing. Pemberdayaan melalui latihan kerja antara lain: Pembuatan Furnitur dan Mebel rumah tangga, Alat-alat rumah tangga, Produksi Paving Stone manual, Kerajinan kayu untuk playgroup, Lukisan dan Lukisan Rajutan (streaming), Percetakan dan Offset, Pembuatan Pot Tanaman, Tanaman Hias, dan Berternak ikan nila dan lele. Dengan demikian, melalui pemberdyaan latihan-latihan tersebut semkin memandirikan anak-anak disabilitas dalam kehidupannya setiap hari.

\section{DAFTAR PUSTAKA}

Adi, Rukminto, Isbandi, 2003. Pemikiran-Pemikiran dalam Pembangunan Kesejahteraan Sosial, Lembaga Penerbit, Fakultas Ekonomi, Universitas Indonesia.

Bhakti Luhur. Unit-Unit Sosial Balai Latihan Kerja. Online. http://www.Bhaktiluhur.Org/UnitUnit-Sosialbalai-Latihan-Kerja/Balai-Latihan-Kerja-Di-Malang-Setaman, (diakses pada tanggal 30 September 2020)Edi, Suharto, 2010. Membangun Masyarakat Memberdayakan Rakyat, Bandung: Rafika Aditama.

Foy, Nancy, 1994. Empowering Peopleat Work, London: Grower Publishing Company Joppy, Liando dan Aldjon Dapa, 2007. Pendidikan Anak Berkebutuhan Khusus Dalam Perspektif Sistem Sosial, (Jakarta: Departemen Pendidikan Nasional,).

Lexy, J. Moleong, 2010. Metode Penelitian Kualitatif Edisi Revisi, Bandung: PT. Remaja Rosdakarya.

N.N. 2016. Pemberdayaan Penyandang Disabilitas Yayasan Bahtera. Online. http://Www.Temuinklusi.Sigab.Or.Id/2016/Wp-Content/Uploads/2016/08/ 


\section{PEMBERDAYAANPENYANDANG-DISABILITAS-YAYASAN-BAHTERA.PDF,}

(diakses pada Tanggal 30 September 2020).

Peter, Coleridge, 1997. Pembebasan dan Pembangunan: Perjuangan Penyandang Cacat di

Negara-negara Berkembang. Penerjemah: Omi Intan Naomi, Yogyakarta: Pustaka Pelajar

Ritzer, George, 2012. Teori sosial. Bandung: Nusamedia

Undang-Undang No. 19 Tahun 2011 tentang Pengesahan Convention On The Right Of Persons

With Disabilities (Konvensi Mengenai Hak-Hak Penyandang Disabilitas) (online) dalam (http://hukum.unstrat.ac.id/uu/ 2011 19.pdf) (diakses pada tanggal 30 September 2020).

Undang-Undang Nomor 8 Tahun 2016 tentang Penyandang Disabilitas Dan Peraturan Daerah

Provinsi Jawa Timur Nomor 3 Tahun 2013 Tentang Perlindungan Dan Pelayanan Bagi Penyandang Disabilitas

Warsito, dkk., 1997. Sistem dan Pola Pendekatan Penyaluran Kerja, Surakarta: PPRR UNS. 